Marquette University

e-Publications@Marquette

Biological Sciences Faculty Research and

Publications

Biological Sciences, Department of

$1-1-1979$

Effects of Thyrotoxicosis on Mitochondrial Enzymes of Rat Soleus

James B. Courtright

Marquette University, james.courtright@marquette.edu

Robert H. Fitts

Marquette University, robert.fitts@marquette.edu

Published version. Hormone and Metabolic Research, Vol. 11, No. 4 (1979): 304-306. DOI. (C) 1979 Georg Thieme Verlag (an imprint of Thieme Publishing). Used with permission. 
Horm. Metab. Res. 11 (1979) 304-306

\title{
Effects of Thyrotoxicosis on Mitochondrial Enzymes of Rat Soleus
}

\author{
J.B. Courtright and R.H. Fitts \\ Department of Biology Marquette University, Milwaukee, Wisconsin, U.S.A.
}

\begin{abstract}
Summary
Cytochrome oxidase, glycerol-3-phosphate dehydrogenase, and succinate dehydrogenase were measured in mitochondrial fractions obtained from rat soleus muscle of control and 8 week $T_{3}+T_{4}$ treated animals. Under these conditions of prolonged treatment, there is a five-fold increase in the specific activities of both cytochrome oxidase and glycerole-3-phosphate dehydrogenase. Significant increases in total cellular mitochondrial content and enzyme activities were observed in $T_{3}+T_{4}$ treated animals as compared to controls. These results indicate that thyrotoxicosis can induce selective changes in mitochondrial enzymes in slow twitch red (Type I) muscle fibers
\end{abstract}

Key-Words: Thynotoxicosis - Mitochondrial Enzymes Rat Soleus Muscle

\section{Introduction}

In previous studies thyroid hormone administration porduces no significant effects on either hindlimb skeletal muscles or isolated gastrocnemius and vastus lateralis (Lee and Lardy 1965; van Hardeveld, Rusche, and Kassenaar 1976). Isolated soleus, however, exhibits biochemical (Winder and Holloszy
1977) and physiological (Fitts, unpublished observa. tions) alterations which indicate that this muscle, composed predominantly of Type I fibers, is respon. sive to long-term thyroid hormone administration. We have re-examined the effects of thyroid hormone on rat soleus and in this communication present evidence which indicated there are significant increases in selected mitochondrial enzymes of this muscle fiber type.

\section{Materials and Methods}

Animal Care and Thyroid Administration. Female rats of a Wistar strain were obtained from Carnworth Farms and provided with food and water ad libitum and were housed in individual cages in a room maintained at $23^{\circ} \mathrm{C}$. For the administration of thyroid hormones, the rats were fed for 8 weeks a diet of powdered Purina chow with $3 \mathrm{mg} \mathrm{T}$ and $1 \mathrm{mg} \mathrm{T} / \mathrm{kg}$. Control animals which received no supplemental thyroid hormones were maintained under identical conditions.

Preparation of Homogenates. For each experiment, five rats were anesthetized with sodium pentobarbital; the soleus muscles were weighed extracted, pooled, and homogetr ized in $0.1 \mathrm{M} \mathrm{KCl}-5 \mathrm{mM} \mathrm{MgCl}-5 \mathrm{mM}$ EGTA-0.25 M sucrose and $25 \mathrm{mM}$ imidazole, $\mathrm{pH}$ 6.8. Crude cell debris was re 
moved by centrifugation for $10 \mathrm{~min}$ at $800 \mathrm{xg}$ and the mitochondrial fraction obtained after centrifugation for $20 \mathrm{~min}$ at $8000 \mathrm{xg}$. The entire mitochondrial pellet was resuspended in $0.1 \mathrm{M} \mathrm{KCl}-0.1 \mathrm{M} \mathrm{DL}-$ glycerol-3-phosphate, $\mathrm{pH} 8.0$, centrifuged for $15 \mathrm{~min}$ at $27,000 \mathrm{xg}$, resuspended in KCL-DL-glycerol-3-phosphate, and was used immediately for the determination of enzymatic activities.

Enzyme Assays. Cytochrome oxidase (E.C. 1.9.3.1) was measured in the spectrophotometric assay of Phan and Mahler (1976) and values are expressed as the first order zate constant, $\mathrm{k}$, per min per milligram protein at $25{ }^{\circ} \mathrm{C}$. Glycerol-3-phosphate dehydrogenase (E.C. 1.1.99.5) and succinate dehydrogenase (E.C. 1.3.99.1) were assayed as previously described (Courtright 1975) and values are expressed in terms of nanomoles product formed per minute. Protein concentrations were determined using the method of Lowry et al. (1951). Specific activities are expressed as units per milligram protein.

\section{Results and Discussion}

Rats maintained for 8 weeks on the $\mathrm{T}_{3}$ and $\mathrm{T}_{4}$ dietary regimen exhibited typical features of thyrotoxicosis, including increases in cardiac and hepatic weights and increased sarcoplasmic reticulum ATPase activities (Winder, Baldwin, Terjung and Holloszy 1975; and Fitts, unpublished observations). As seen in Table 1, the total mitochondrial protein per gram of tissue from the soleus of treated animals was significantly greater than that of control animals.

However, in contrast to the $33 \%$ increase in mitochondrial concentration, there was more than a $800 \%$ increase in cytochrome oxidase and glycerol-3-phosphate dehydrogenase activities when calculated per gram soleus. These increases apparently reflect selective induction of these mitochondrial enzymes since there is more than a five-fold increase in the specific activities (Table 1) while there is no significant change in the specific activity of succinate dehydrogenase.

The selective increase in both cytochrome oxidase and glycerol-3-phosphate dehydrogenase appears to parallel the increase in cytochrome c during thyrotoxicosis (Winder, Baldwin, Terjung and Holloszy

Table 1 Effect of thyroid hormone on the mitochondrial and enzyme content of soleus

\begin{tabular}{|c|c|c|}
\hline & Control & Experimental \\
\hline Yitochondria $(\mathrm{mg} / \mathrm{gm})$ & $17.1 \pm 0.6$ & $25.7 \pm 3.5^{*}$ \\
\hline $\begin{array}{l}\text { Cytochrome oxidase } \\
\text { (k/mg protein) } \\
\text { Glycerol-3-phosphate de- }\end{array}$ & $21.5 \pm 5.5$ & $112 \pm 12^{* *}$ \\
\hline $\begin{array}{l}\text { Glycerol-3-phosphate de- } \\
\text { hydrogenase (nmol/ } \\
\text { min/mg protein) }\end{array}$ & $4.8 \pm 1.4$ & $28.3 \pm 4.1 * * *$ \\
\hline $\begin{array}{l}\text { Succinate dehydrogenase } \\
\text { (nmol/min/mg protein) }\end{array}$ & $55 \pm 16$ & $44 \pm 6$ \\
\hline
\end{tabular}

Values are means $\pm \mathrm{SE}$.

Results are expressed per gram wet weight of pooled soleus Results are expressed per gram wet weight of pooled soleus
muscles from 5 animals or per milligram mitochondrial protin, $\mathrm{N}=4$.

"Control vs. $\mathrm{T}_{3}+\mathrm{T}_{4}$-treated, $\mathrm{P}<0.1$

"Control vs. $\mathrm{T}_{3}+\mathrm{T}_{4}$-treated, $\mathrm{P}<0.002$

"Control vs. $\mathrm{T}_{3}+\mathrm{T}_{4}$-treated, $\mathrm{P}<0.001$
1975; Winder and Holloszy 1977). It is also noteworthy that both enzymes may be composed of polypeptide components synthesized on mitochondrial ribosomes (Schatz and Mason 1974) which are apparently synthesized at higher rates during thyrotoxicosis (Baudry, Clot, Bouhnik, Michel and Michel 1976).

In previous studies on the induction of glycerol-3phosphate dehydrogenase, no significant increase in this enzyme activity could be found in extracts prepared either from skeletal muscle (Lee and Lardy 1965; Lee, Tasemozi and Lardy 1959; Winder et al. 1975 ) or from isolated gastrocnemius and vastus lateralis (van Hardeveld, Rusche and Kassemaar 1976). This failure to find significant changes in these muscles during thyrotoxicosis may be due to the fact that these samples were primarily composed of Type IIA and IIB (fast twitch fiber types) which differ in a number of biochemical and physiological parameters from the slow twitch muscle (Type I), which composes $85 \%$ of rat soleus (Brooke and Kaiser 1970; Peter, Barnard, Edgerton, Gillespi and Stemple 1972; Ariano, Armstrong and Edgerton 1973). It seems likely that the response of soleus to prolonged $T_{3}+T_{4}$ administration provides yet another biochemical characterization of this fiber type and may indicate that soleus has different receptors for these hormones.

\section{Acknowledgements}

This work was supported by Marquette Faculty Research Grant No. 5645 .

\section{References}

Ariano, M.A., R.B. Armstrong, V.R. Edgerton: Hindlimb muscle fiber populations of five mammals. J. Histochem. Cytochem. 21: 51 (1973)

Baudry, M., J.P. Clot, J. Bouhnik, O. Michel, R. Michel: Thyroid hormone action on electrophoresis patterns of rat liver and muscle mitochondria. Thyroid Research (Robbins and Braverman, Eds.) pp. 351. Elsevier, North Holland, New York (1976)

Brooke, M.H., K.K. Kaiser: Muscle fiber types: how many and what kind? Arch. Neurol. 23: 369 (1970)

Courtright, J.B.: Intracellular localization and properties of glycerokinase and glycerophosphate dehydrogenase in Neurospora crassa. Arch. Biochem. Biophys. 167: 21 (1975)

Lee, Y.P., H.A. Lardy: Influence of thyroid hormones on L- $\alpha$-glycerophosphate dehydrogenase and other dehydrogenases in various organs of the rat. J. Biol. Chem. 240: 1427 (1965)

Lee, Y.P., A.E. Takemori, H.A. Lardy: Enhancement of the oxidation of $\alpha$-glycero-phosphate by mitochondria of thyroid-fed rats. J. Biol. Chem. 234: 3051 (1959)

Lowry, O.H., N.J. Rosebrough, A.L. Farr, R.J. Randall: Protein measurement with the Folin phenol reagent. J. Biol. Chem. 193: 265 (1951)

Peter, J.B., R.J. Barnard, V.R. Edgerton, C.A. Gillespie, K.E. Stemple: Metabolic profiles of three fiber types of skeletal muscle in guinea pigs and rabbits. Biochemistry 11: 2627 (1972) 
Phan, S.H., H.R. Mahler: Studies on cytochrome oxidase. Partial resolution of enzymes containing seven or six subunits from yeast and beef heart, respectively. J. Biol. Chem. 251: 257 (1976)

Schatz, G., T.L. Mason: The biosynthesis of mitochondrial proteins. Ann. Rev. Biochem. 43: 51 (1974)

van Hardeveld, C., R. Rusche, A.A.H. Kassenaar: Sensitivity of mitochondrial $\alpha$-glycerophosphate dehydrogenase to thyroid hormone in skeletal muscle of the rat. Horm Met. Res. 8: 153 (1976)

Winder, W.W., J.O. Holloszy: Response of mitochondria of different types of skeletal muscle to thyrotoxicosis. Am. J. Physiol. 232: C180 (1977)

Winder, W.W., K.M. Baldwin, R.L. Terjung, J.O. Holloszy: Effects of thyroid hormone administration on skeletal muscle mitochondria. Am. J. Physiol. 228:1341 (1975)

Requests for reprints should be addressed to: James B. Courtright, Department of Biology, Marquette University Milwaukee, Wi. 53233 (U.S.A.) 